\title{
Local Area Development through Hydropower Project: A Case Study of Parbati Hydro-Electric Project Stage-III (520MW) in Kullu district of Himachal Pradesh (India)
}

\author{
Manoj Kumar Singh ${ }^{1}$ and Ashish K. Dash ${ }^{2}$ \\ ${ }^{1}$ Environment and Diversity Management Division, NHPC Limited, Sector-33, Faridabad (Haryana) India \\ ${ }^{2}$ NHPC Limited, Parbati HEP-II, Nagwain, District-Mandi, Himachal Pradesh, India
}

\begin{abstract}
The objective of study is to assess and evaluate the Local area development (LAD) in Sainj valley following the start of construction of Parbati HE Project-III in the Year 2006 by NHPC Limited (a Government of India Enterpriseminiratna). The assessment of local area development is based on comparison of baseline data of Sainj area prior to start of construction of project and data available during construction phase of project followed by reviewing of Govt. policy for Local Area Development Fund (LADF) in project affected area and consultation with people from project affected gram-panchayats located in the vicinity of construction sites to know their perception about the role of Parbati hydroelectric Project Stage-III in local area development of Sainj valley. The result of study shows that there is substantial increase in developmental activities in and around the project area due to the construction of Parbati HE Project-III. Particularly, infrastructural development (road-bridge) led to improvement in communication and accessibility of villages (Manham, Banau, Sapangini,Talara) in Sainj valley, better transport facility for horticulture products of farmers in Sainj valley to nearby market located on NH-21. The prospects of job opportunities in Project construction works, ancillary activities and in petty contract works also improved. Implementation of community development Schemes of NHPC led to availability of additional medical facilities, educational facility in Govt. Schools and development of socio-cultural aspects (Crematorium, melaground, toilets,watersupply etc) in Sainj valley are attributed to the construction of Parbati HEP-III. During construction phase of the project, in compliance to Govt. policy for LADF @ 1.5\% of project cost allocated for execution of developmental works resulted in source of specific fund for development opportunity in Project affected area(PAA) in the valley and nearby areas. Out of total LADF for PAA, $60 \%$ was shared equally among three project affected gram-panchayats and remaining $40 \%$ among 04 gram-panchayats for taking-up developmental works by resolution of Gram-Shaba and local area development Committee(LADC). Also, during operational phase of Project, the provision of LADF @ 1\% share of free power and revenue equivalent to 12\% share of free power to State Govt. of Himachal Pradesh from Parbati HEP-III on annual basis through-out the life span of project are continuous source of financial gain from Parbati HEP-III which will act as a stimulus for development.
\end{abstract}

Key Words: Hydropower, IHR, Energy, Local area development, Sainj valley

\section{Introduction}

The Indian Himalayan Region (IHR) with its major river systems and variation in topographical features has vast hydropower potential to generate electricity from flowing water with a hydraulic gradient (Price, T. and Probert D, 1997). IHR accounts for $67 \%$ of Himalayan region and approximately $18 \%$ of India's total geographical area and contrarily own more than 75\% (117.139 MW) of total exploitable potential (Agrawal DK et al., 2001). Harnessing of hydroelectric potential are in different stages of development like operation, construction and investigation stages. The people of IHR, like elsewhere in other mountain ecosystem, are heavily dependent for their livelihood on their immediate natural resources and production from primary sectors such as agriculture, forestry, horticulture, livestock, etc. Despite the abundance of natural resources, most of its people are marginalized and still live on subsistence level (Singh, 2006). Sustainable harnessing of hydropower projects (HPPs) in IHR offer a means of local area development around project area in particular and provide clean, economic and renewable source of electricity to the nation.

This article is distributed under the terms of the Creative Commons Attribution License, which permits unrestricted use and redistribution provided that the original author and source are credited.

ISSN 2330-2887 Online |c 2017 The Author(s) Published by World Scholars: http://www.worldscholars.org 
There is close linkage between energy and the social dimension of the sustainable development. Energy is absolutely essential to deliver adequate services, food, water, health care, education, shelter, and employment and therefore the access to sustainable energy is a key factor for promoting social progress and economic growth (Najam and Cleveland, 2008, Kahssay and Mishra, 2013; Goldemberg and Johansson, 1995). In our increasingly carbon constrained world, renewable energy forms, such as hydropower and wind power, have the potential to meet the economic, social, environmental, and sustainability criteria demands of our times(Paul Schuler 2007). Hydropower is a renewable and green source of energy, which is economic (Chandrasekharan,1995; Subrahmanyam 2013) reliable to manage fluctuation of electric power and has flexibility to open and close gate to control demand of power (Bhoi \& Ali, 2014). It is the least expensive source of electricity when compared to nuclear and coal plants (Singh et al, 1991). Hydroelectric projects have long useful life extending over 50 years and help in conserving scarce fossil fuels (CEA, 2008).

At the World Summit on Sustainable Development (Johannesburg in 2002), a commitment was made to increase hydropower production as a means of addressing environmental concerns and the successful initiation of the hydroelectric project may also contribute in obtaining the Millennium Development Goal(MDG) put forth by United Nation (Kahssay and Mishra, 2013).

Looking into the perspective of social dimension of Sustainable development, basic infrastructure such as Roads, reliable supply of electricity, water supply, health facilities etc is required for a particular region. The setting-up of HPPs in IHR offer a prospect of development of local area. Generally, during the planning and preliminary investigation stage of HPPs, the best alternative site are selected on the basis of hydraulic gradient (net head), flow regime and minimum displacement of inhabitants as well as impact on environment. On techno-economic evaluation, suitable sites for hydropower project appurtenance such as water diversion structure (dam/barrage), tunnel, powerhouse etc are located in remote hill terrain which lacks proper access road, bridge and other civic infrastructure facility such as water supply lines, hospitals, markets, reliable supply of electricity etc (Subrahmanyam-2013).

Implementation of HPPs in such area is challenging in view of topographical features, fragile ecology and compliance of environmental norms as per conditional statutory clearances and budget accorded by Government. In order to ensure timely and cost-effective implementation of HPPs in such area, infrastructural facilities like construction of access road, bridges, strengthening of existing bridge and widening of existing roads, efficient and reliable tele-communication links, better rail transport, postoffice, bank, market etc are developed at a faster pace by expeditious efforts of project developers with the help of local Govt. machinery. Development of these infrastructures in the region also help in opening avenues for development of remote and hitherto backward hilly areas by giving accessibility of these facilities and connectivity to nearby town to increase socio-economic activities. On start of Project construction activities, the scope of employment in construction works, self employment in project ancillary works and marketing avenues are increased. The study conducted by Panwar et al 2013, Subrahmanyam 2013, Bose et al., 2001 and Altinbilek, 2002, indicates that Hydropower projects create many direct jobs and associated demands for goods and services besides infrastructures i.e., electricity, roads, water supply and distribution network etc., which act as stimulus for further development and economic growth both in direct and indirect way. All these facilities help in local area development and improving the quality of life of the inhabitants. After commissioning of project, supply of clean and cheap electricity boost the industrial development of area. Hydropower projects contribute much more than renewable energy through the storage capacity of reservoirs by providing essential services such as water supply, flood control, irrigation, fisheries, recreational opportunities, navigation etc. Goudie and Viles, 1997 has urged that dam is extremely successful in meeting the needs of "surrounding communities,": millions of people depend upon them for survival, welfare and employment. The beneficiaries of these facilities are mainly local population.

Moreover, Govt. policy for Hydropower development and provision of Local Area Development Fund(LADF) also paved the way for development of local area nearby hydro-power projects sites throughout the life span of project(HPP2008,GoI, LADA-2006,GoHP ). As per Govt. of Himachal Pradesh's guideline for Local Area Development Activities (LADA) during construction phase of HPPs, project developer has to contribute LADF@1.5\% of total estimated cost of Project to State Govt. for executing local area development works in project affected gram-panchayats and nearby area. Also, in compliance to Hydropower Policy-2008 (Govt.of India), corpus fund for Local area development would be generated by contribution of Project developers to the tune of $1 \%$ power generated from Project and host State Government would also to provide a matching contribution of $1 \%$ from their share of $12 \%$ free power received from project 
developer after commissioning of HPP. LADF is aimed at providing a regular stream of revenue for income generation and welfare schemes, creation of additional infrastructure and common facilities etc on a sustained and continued basis over the life of project. The management of LADF is to be done by committee comprised of State Govt., representative of Project affected Family and Head of HEP.

Another source of local area development on sustained basis is 'profit-sharing mechanism' i.e implementation of Corporate Social Responsibility (CSR) schemes by project developer(company) for the development of local area and area around it where it operates in terms of clause-135 of the Indian Company Act-2013 (The Company Act-2013,GoI). Under CSR scheme, various development activities in the field of health, education, income generation, infrastructure etc as listed in schedule VII of company Act-13 are to be taken up by company and fund required thereof are to be met out of the profit of company. Implementation of CSR activities is mandatory as per Company Act2013 and therefore it is a source of development in and around HPPs.

Looking into the above prospects of development due to construction of HPPs, in the present study, an attempt has been made to assess and evaluate the local area development in Sainj valley (Project area) following the construction of Parbati Hydro power Project Stage-III (520MW) in Himachal Pradesh by ' $N H P C$ Limited'. NHPC is a Government of India Enterprise of miniratna category established in 1975 for sustainable harnessing of Hydropower. As on $31^{\text {st }}$ January2017, total 22 nos. of hydropower projects with installed capacity of 6717 MW have been commissioned by NHPC in India besides construction of HPPs in Nepal and Bhutan.

\section{The Study Area}

The Himachal Pradesh, a part of trans and northwestern bio-geographic provinces of the IHR has total hydro-potential of $20415 \mathrm{MW}$ in the six river basin namely Yamuna, Satluj, Beas, Ravi and Chenav. All the rivers are snow-fed and therefore rich in water resources and supporting enough for the generation of electricity. Parbati Stage-III(520MW) is one of the hydropower scheme located in Beas basin on the River Sainj in Kullu district, a part of North-Western Himalayas in Himachal Pradesh (India). The district comprises six sub-tehsil viz. Kullu, Manali, Sainj, Banjar, Aani and Nirmand. Study area is located between $31^{0} 43^{\prime}-31^{0} 46^{\prime} \mathrm{N}$ latitudes and $77^{0} 13^{\prime} 45^{\prime}$ '. $77^{0} 20^{\prime} \mathrm{E}$ longitudes in sub-tehsil Sainj of Kullu district (Fig-1). In Kullu district, there is a distinct geographical place known as 'the Beas Valley" in the northwestern himalaya. Beas valley consists of four sub-valleys named as the Kullu, the Parbati, the Garsa and the Sainj. The Sainj valley covers $37.9 \mathrm{~km}^{2}$ area and situated in the south of the Kullu district in Himachal Pradesh. Project area (Dam site to Power house site) is located in 07 Gram-panchayats in Sainj valley starting from village Suind (Dam Site) to Larji(TRT site) in Sainj valley along the direction of flow of River Sainj on left bank. The area exhibits a rugged topography with high mountains and steep slopes. The Sainj River flows in the valley is a major tributary of the Beas River that originates from west of Rakti Dhar at an elevation of 5500m. It follows almost in east-west direction down to the dam site near village suind and then turns from the northeast to the southwest before traverses in the west before joining river Trithan(near village Larji). Both Trithan and Sainj confluence with river Beas near a place called Aut on NH-21(Chandigarh to Manali). 


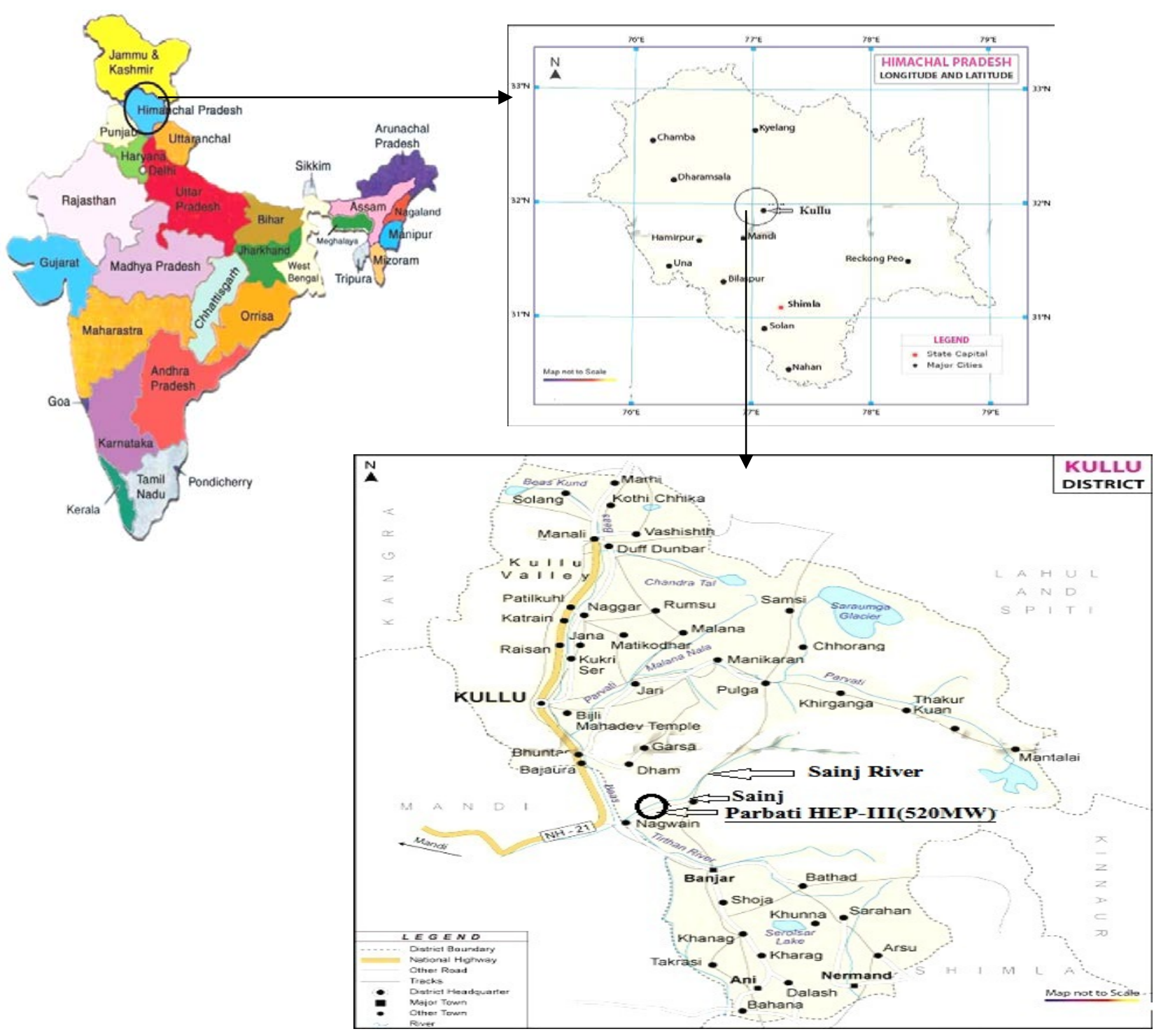

Figure 1: Location of Parbati HEP-III in Kullu district of Himachal Pradesh(India)

The Sainj river catchment area comprises of rich and diverse vegetation due to its large altitudinal range, diverse soil and climatic conditions. The Sainj valley is mainly represented by sub-tropical, temperate, subalpine and alpine types of vegetation. Sub-tropical forests are mainly dominated by Chir Pine (Pinus roxburghii). Temperate and sub-alpine forests are mainly dominated by broad leaved deciduous and evergreen coniferous species, and meadows are dominated by alpine shrubs and herbaceous species. The valleys are mainly dominated by settlements and horticultural and agro-forestry species for medicinal, food (edible), fuel, fodder, house building, making agricultural tools, fiber, religious and various other purposes of inhabitants (Samant et al 2007).
However, to a considerable extent, the villagers augment their income by rearing sheep and goats for wool and meat and collecting Guchhi Mushroom (Morchella esculenta). There are very few people who do service (Salaried Job). Extraction of medicinal herbs and collection of Guchhi has been their traditional source of income generation.

Presently, Sainj valley encompasses four Hydroelectric projects namely Sainj Hydro-Electric Project (100MW) and Parbati Hydro-Electric Project, StageII (800MW) which are under construction whereas Parbati Hydro-Electric Project, Stage-III (520MW) and Larji Hydroelectric project (126MW) that are already commissioned. 


\section{Parbati HE Project Stage-III(520MW)}

PHEP-III is a run-of-the river scheme of river Sainj with a proposed power generation capacity of 520MW (130MW X 4 units) from 43m high rock-fill dam at EL 1333m (m.s.l) and design discharge of 177Cu.M water from $7.8 \mathrm{~km}$ HRT to Power House. Dam is located at village Suind, about $500 \mathrm{~m}$ downstream of Powerhouse of Parbati HE Project(Stage-II) in between $31^{\circ} 46^{\prime} \mathrm{N}$ and $77^{\circ} 15^{\prime} \mathrm{E}$ (Fig-1). The Parbati HE Project Stage-III is utilizing water from river Sainj as well as water from River Parbati released from tail race of the Parbati HE Project (Stage-II) after using its water in power house at Suind, which ultimately discharges into river Sainj within the reservoir area of dam of Parbati HE Project(Stage-III). An underground powerhouse has been constructed near village Behali about $3 \mathrm{~km}$ from Aut, a place on National Highway-21 at about $190 \mathrm{~km}$ from Shimla and $500 \mathrm{~km}$ from Delhi. The construction of project started in 2006 after accord of statutory clearances from Govt. of India at total approved Project cost of Rs 2304.55 Cr. Presently, all the four units (130MW $\mathrm{x} 4$ ) of project are commissioned in phased manner starting from Sept 2013 to June 2014. The project is designated to generate 1963 million units/year of electricity covering $90 \%$ time of a year at $95 \%$ period of total availability of machinery. The electricity is evacuated to northern regional grid for further distribution to six beneficiary states namely Rajstahan, J\&K, UT Chandigarh, Delhi, Haryana \& Punjab as per Power Purchase Agreement(PPA) and providing share of $12 \%$ free power to Govt. of Himachal Pradesh as per memorandum of understanding with NHPC.

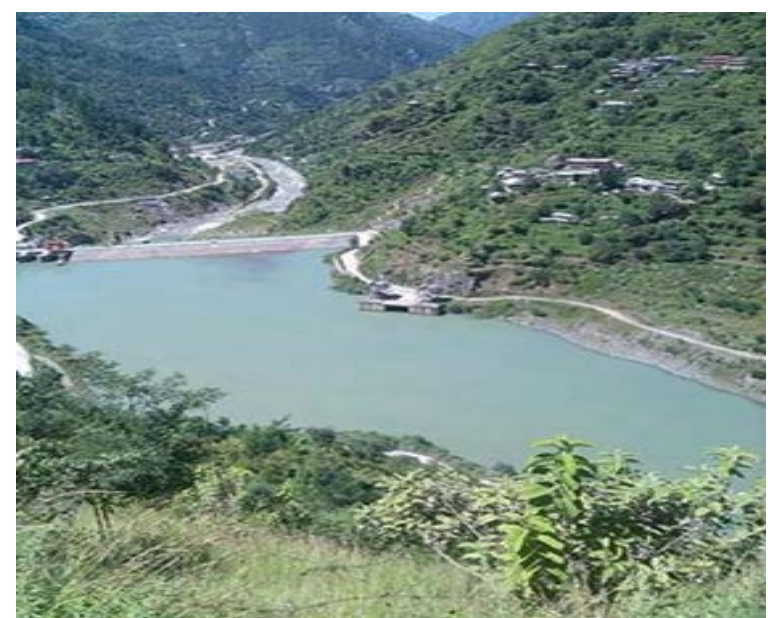

Dam site of Parbati HEP-III: upstream \& downstream view

\section{Climate and Rain fall}

Sainj valley is represented by mainly four seasons ie., summer(April-june), Rainy(July-September), Autum(October-November) and winter(DecemberMarch). Winter season faces severe climatic conditions. The temp goes down to $0^{0} \mathrm{C}$ during winter and $39^{\circ} \mathrm{C}$ during summer. January is the coldest month and June is the hottest month. During rainy season, area receives rainfall under the influence of south-west monsoons. Winter precipitation occurs in association with the passage of western disturbances. The annual average rainfall in the project area is $1459.2 \mathrm{~mm}$.

\section{Geology}

Rock type is important for hydroelectric projects as the majority of civil structures such as powerhouse, Head Race Tunnel, Tail Race Tunnel etc. are underground/sub-surface. Geologically, Project area falls within the greater and lesser Himalayan zones. The area is bound by Main Central Thrust (MCT) in the north and towards extreme south by Main Boundary Faults (MBF). Project appurtenances are constructed along the left bank of the Sainj river valley. The project area illustrates a complex geology where various rock formations have undergone considerable deformations. The civil structures viz. Power house area, TRT are located in Larji formation whereas Dam is located in Banjar formation (Green bed member). HRT is located in both Banjar and Larji formation (DPR 2003). The project area falls under seismic zone-V, as per IS: 1894: 2002.

\section{Methodology}

The methodologies employed in the present study are site selection, collection of baseline information from secondary source such as Detailed Project Reports(DPR) of Parbati HEP-III, Govt. Notifications, policy, Land acquisition data etc. Primary information was obtained from tripartite meetings of project developer (NHPC) held with representative of project affected gram-panchayats and district administration being the main stakeholders of Project. The feedback of villagers about development aspects of project was gathered through informal discussion in various sessions during the construction phase of project. In order to align villagers with development, meetings and regular interactions with villagers is very important for project officials to know their problems and expectations from Project. Based on which suitable measures are taken beforehand to avoid any strike causing cost-time overrun of project. Data collected through primary and secondary sources were systematically arranged and interpretation was made to draw result of study. 


\section{Result and Discussion}

Land is the prime resource for setting-up of HPPs by acquisition of private land and diversion of forestland. Therefore, the priority of benefits of HPPs is given to project affected area (PAA) where project is established. In Parbati H.E Stage-III project, total 139 ha land located in 07 gram-panchayats of Sainj valley was required for construction of project components. The percentage of land acquired and location of project components in 07 gram-panchayats are shown in Fig. 2 and 3 respectively. These 7 gram-panchayats are prime beneficiaries of local area development due to construction Parbati HEP-III.

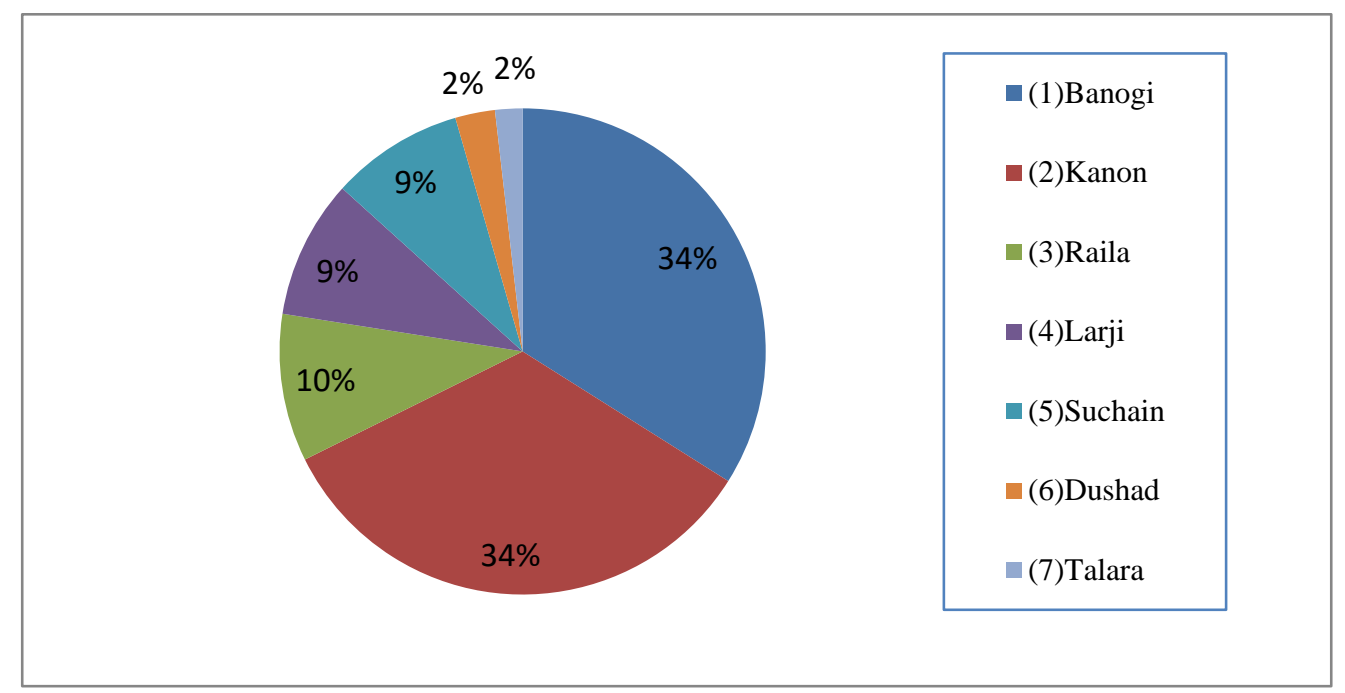

Figure 2. Land acquired (\%) in 07 Gram-Panchayats for Prbati HEP-III

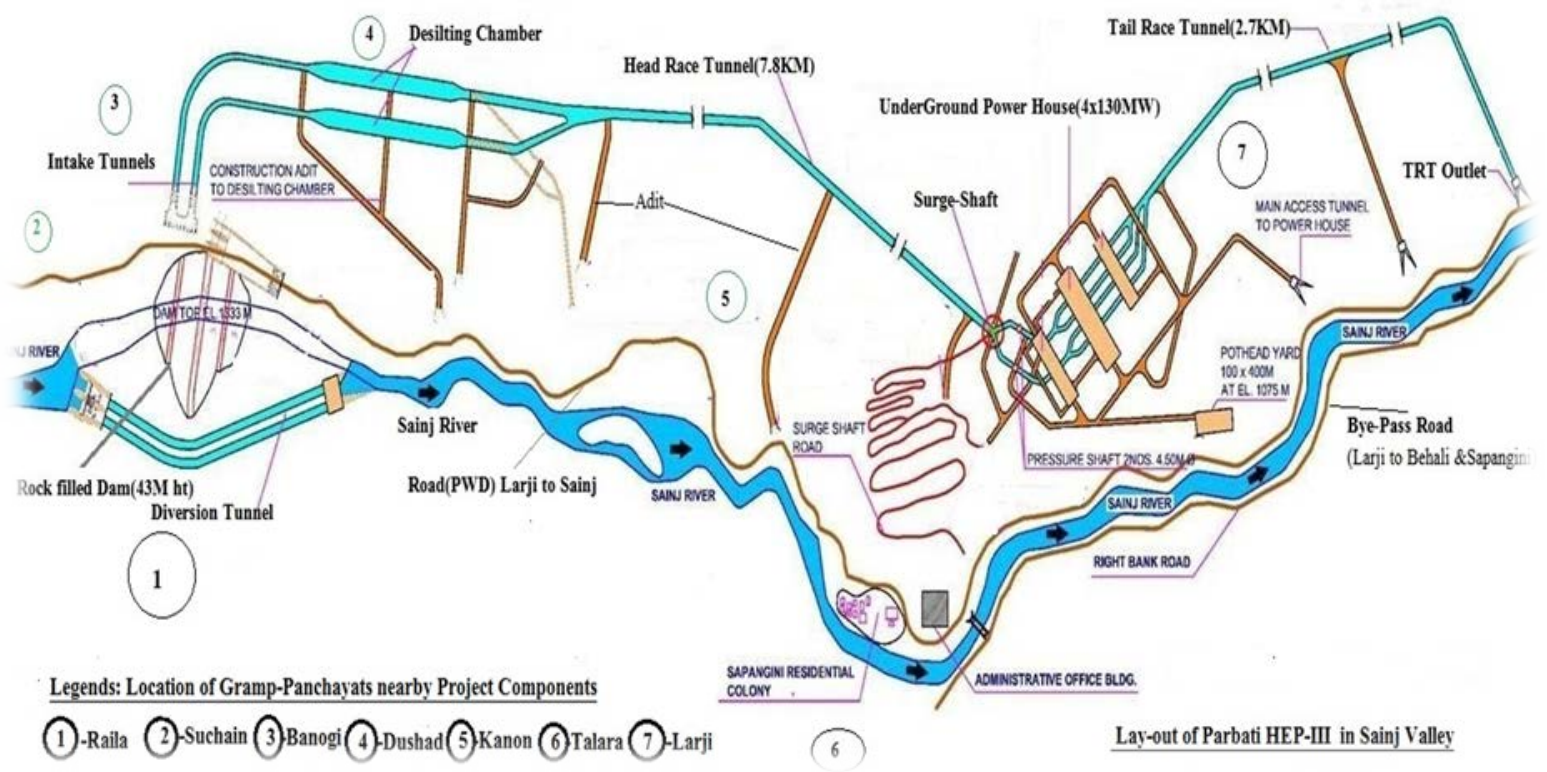

Figure 3: Location of Project Components in 07 gram-panchayats(PAA) in Sainj valley. 
As depicted in Fig.3, the project area starts from Dam site (located in three Gram-panchayats:Raila(1), Suchain(2)and Banogi(3)) to Tail Race site (located in gram-pamchayat Larji(7)) in Sainj valley along the direction of flow of River Sainj. In between dam and TRT site, other three gram-panchayats (Dushad(4), Kanon(5), and Talara(6)) are under project affected areas where project components such HRT, Road, clay site, dumping sites etc are located. In this area, major construction activities were active from year 2006 to 2013. During this period and in these locations, various types of infrastructure facility required for project was developed by NHPC and community development works were also done for the benefits of people. In addition, local area development fund(LADF) was also released to district administration for executing development works, as illustrated below:

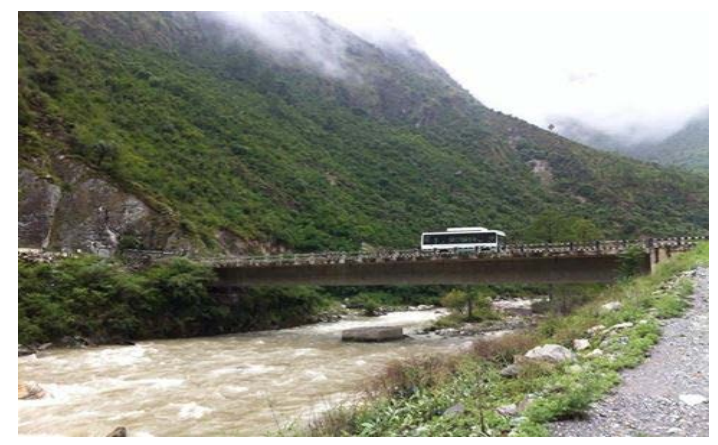

Bridge over River Sainj at Larji village constructed by NHPC Ltd

Road and Bridge: Access roads and bridges are required for establishment of HPPs in remote hilly terrain. In Sainj valley, development of road and bridge due to construction of Parbati HEP-III and its consequent benefits to different gram-panchayats were compared (Table-1) with the baseline data e.g status prior to start of construction of Parbati HEP-III. It is found that prior to start of construction of project in year 2006, there was a single-lane narrow road along the left bank of river sainj named 'Larji-Sainj state PWD-road' (A(i) of Table-1) connecting Sainj valley to National highway-21(Chandigarh-manali) near village Aut. Following the start of construction of Parbati HEP-III, four new roads(A-ii to iv of table-1) were constructed and two existing roads(A-i, vi of Table-1) were widened from single-lane to two-lane for smooth movement of vehicles in hilly tarrain. Similarly, three new bridges(B-i,ii,iv of table-) were constructed and one old bridge(B-iii of table-1) was strengthened to increase load bearing capacity for safe movement of heavy vehicles and traffic. Although, these infrastructure were developed keeping in view of the specific requirement of project to access construction sites of project and also to divert heavy traffic of project vehicles to reduce inconvenience to local people. These road and bridge are now giving inter-connectivity among 07 gram-panchayats and nearby area and connectivity to remote villages (Banau, Manham,Talara,sapangini, upper sainj) which were hitherto not connected earlier (as shown in Table-1). Availability of good roads and bridges in Sainj valley resulted in increase in safe mode of road transport and frequency of plying of vehicles, decrease in time taken to travel and maintenance cost of vehicles as well. Also, effective road communication leads to enhancement in economic activities particularly transport and sale of field products (vegetables, fruits) and handicrafts of villagers in the better market options available in nearby subji-mandi at Panarsa, Bhunter and Mandi located on National Highway (NH)-21. In this way, increase in road \& bridge infrastructures in Sainj valley is attributed to Parbati H.E Project Stage-III.

It is a fact that construction of road and bridge in hilly terrain is time taking and very costly affairs. The Study conducted by Sinclair 2003 reveals that the HP Energy Development Agency (HIMURJA) of Himachal Pradesh had identified some 55 potential micro-hydro sites in the Kullu District. Despite the tremendous potential for hydro development, remoteness, rugged terrain, and particularly the lack of road infrastructure make it difficult to reach many potential sites. Subsequent to the construction of Parbati HEP-III, the infrastructure(Road/bridge) developed for this project is also facilitating the requirement of other two hydroelectric projects namely Parbati HE Project Stage-II(800MW) and Sainj HE Project(100MW) located in the upstream of Parbati HE Project Stage-III on the same river Sainj. Moreover, several micro-hydro sites identified in Sainj valley by HIMURJA shall also be harnessed costeffectively by cutting their cost of expenditure towards infrastructure development (Road,bridge) that would save time as well.

Medical facility: The baseline data of study area shows that prior to start of construction of Parbati HEP-III, there were only one Govt. Primary Health Centre (PHC) located at Sainj for treatment of minor ailment/first aid and another Govt. District Hospital located about $50 \mathrm{~km}$ away at Kullu for advance treatment. After the establishment of Parbati hydroelectric Project-III, fund was contributed by NHPC for up-gradation of existing Government hospitals at Sainj and Kullu town by construction of additional building and providing medical equipments. This led to enhancement in medical facilities in Project Affected Area(PAA) \& near by area called Project Affected Zone(PAZ). In addition, 
two Project dispensaries were opened by project developer(NHPC) at Sainj and Behali which provides medical facilities to project officials as well as villagers, labourer free of cost. Also, under CSR scheme of NHPC, medical camps for general health check-up as well as specific treatment such as cardiac, cataract and veterinary camp are also being conducted in the remote villages of project affected grampanchayat in Sainj valley for villagers and their cattle. In these medical camps, patient are treated free of cost for general check-up, cataract operation, medicines etc under the ongoing development scheme of NHPC for the community residing nearby project area.

Education: To improve the education facilities in project area, infrastructure support (Desk-bench, construction of class rooms, toilets etc) to Govt. schools and scholarship to meritorious students of schools were provided in project affected Grampanchayats as per requirement of schools and discussion held with concerned gram-panchayats. Fourteen nos. of students from 07 gram-panchayats were imparted vocational training through Industrial Training Institute(ITI) at Shamshi(Kullu) and more than 30 nos. of Farmers from Sainj valley were given training for horticulture, medicinal plants through scientists from Y.S.Parmar University of Horticulture and Forestry(Bajaura),Kullu. An innovative step has been taken for opening of Engineering College at Bilaspur (Himachal Pradesh), about $100 \mathrm{~km}$ from Sainj for providing education related to hydropower and to create trained professional for sustainable harnessing of hydropower, operation and maintenance of hydropower stations.

Socio-cultural aspects: Socio-cultural importance of villagers was taken care of during the construction of Parbati HEP-III in Sainj valley. Financial support and sponsorship were provided by NHPC to promote local melas, traditional festival and sports activities. As per consensus of gram-panchayatRaila, a famous sacred 'Laxmi-narayan mela-ground' was developed at Sainj market near dam site by reusing of muck generated from excavation of project sites. Also, other facilities such as crematorium, toilets, river protection, water supply scheme etc were also developed to fulfill the requirement of villagers.

Employment: After the start of construction of project, the prospect of direct and indirect employment increased in Parbati HEP Stage-III. Direct employment was given to 13 members of project affected persons (rendered landless) in accordance to Resettlement and Rehabilitation Plan of Project. Indirect employment in construction activities of project gave rise to engagement of work force of skilled and unskilled type mainly in civil works of project such as excavation and lining of tunnel, dam, Road etc. through two major contractors M/s Jagar-
Gammon and M/s Patel L\&T of project. The local people were given preference in indirect employment because of easy availability of workforce and an agreement between Project proponent (NHPC) and contractors to comply with the Government of Himachal Pradesh's norms to keep ratio of 70:30 for Himachali \& non-Himachali workforce in Project. Besides, local contractors were given preference in awarding petty civil works for installing protection works (wire crate and Random-Rubble masonary) at dumping sites of project and other services such as gardening, cooking, office attendant etc. Some of the villagers from Banau, Larji and Sapangini villages in project area have become well known civil contractors solely due to start of construction of Parbati HEP-III. The scope of self employment and source of income generation were also increased for local people in the form of supplying construction materials to Project, hiring their vehicles in Projects office, hiring buildings for residential/official purposes of project staff and office, opening of various types of shops (Grocery, Canteen, saloon, repairing of vehicle, tyre puncture etc) in project area at village Behali, Larji etc. The existing market at Sainj town near by dam site has improved gradually over 4-5 years and new market with shops containing items of day-to-day needs have been developed at village Behali and Larji near powerhouse site to cater the needs of project officials, workforce and local population. The scope of self employment in taxi service and number of Taxi at Sainj taxi-stand have also increased to cater the need of influx of people in Sainj valley due to project activities of Parbati HEP-III.

Local area development Fund(LADF): Timely commissioning of hydro-power projects(HPPs) is the main concern for Project proponent and State Govt. because of financial aspects linked therewith. After commissioning of HEP, State govt. gets revenue equivalent to $12 \%$ of total electricity generated from each HPP annually. But, most of the HPPs often get delayed in timely commissioning due to various reasons, one of which is strike and opposition caused by local people which leads to time and cost overrun for Project proponent and loss of revenue( $12 \%$ share) to state Govt. To overcome this situation and making local communities to develop interest in expeditious completion of project, a provision of local area development fund (LADF) was introduced by Govt. of Himachal Pradesh through notification issued in year 2006.(LADA-2006,2011) . Notification guides that project developer to contribute $1.5 \%$ of total cost of HPP during the ongoing construction phase to the Deputy Commissioner of concerned district for executing development schemes in Project Affected Gram-panchayats(PAA) and near-by area 'Project affected Zone(PAZ) by constituting district level local 
area development committee(LADC) comprising of representatives from district administration, grampanchayats of project affected area and project developers. The meeting of LADC is convened to decide share of LADF of each gram-panchayat based on quantum of land acquired for HPP as well its adverse impact of project such as submergence, displacement, etc. For execution of any development schemes through LADF in each Gram-panchayat, consensus of villagers for requirement of particular development scheme(s) in village is passed by Gramsabha. Then, these schemes are submitted to LADC meeting for their resolution to consider its execution under the scope of LADF. The corpus of LADF is generated with the District Commissioner by deposition of fund from all Project developers of HPPs located in a district. Subsequently, these schemes are implemented through district administration in each gram-panchayat by sanctioning of share of its LADF. In Parbati HEP-III, as per LADA guidelines, meetings of LADC including representative of affected Grampanchayats and project proponent were held several times to decide sharing of LADF and finalization of proposal for development activities required for project affected area. Accordingly, the share of LADF @ 50\% each to PAA and PAZ was calculated (fig.4) in consultation with LADC considering quantum of land acquired in gram-panchayats and impacts of HEP in PAA.

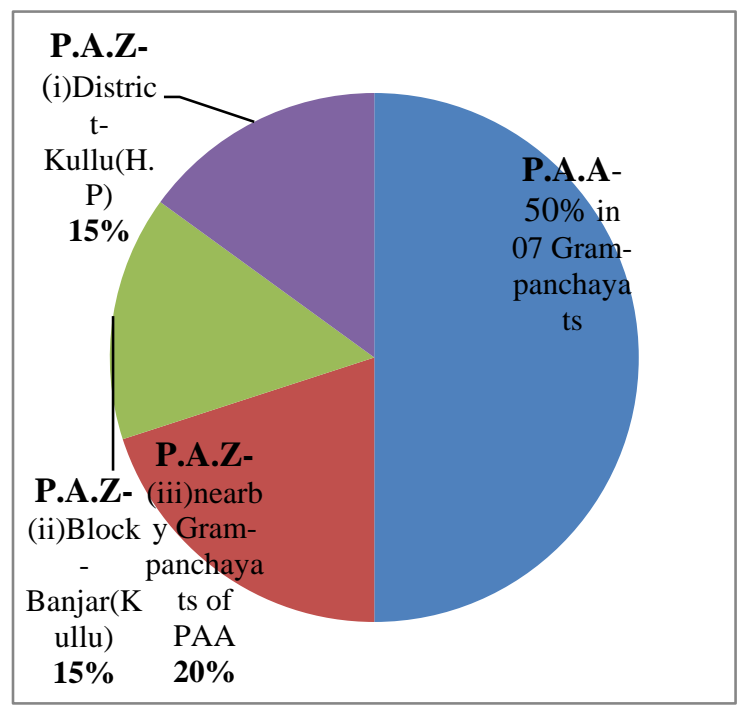

Figure 4: Sharing (\%) LADE among PAA (50\%) and PAZ (50\%)

Out of total $50 \%$ of LADF earmarked for PAA, the share (\%) of LADF among 07 gram-panchayats is depicted in fig-4a. Major part(60\%) of LADF was shared equally by three gram-panchayats(Banogi,Larji and Kanon) @ 20\% of LADF followed by Suchain(15\%), Raila(11\%), Dushad(9\%) and Talara(5\%) as depicted in Fig.-4a.

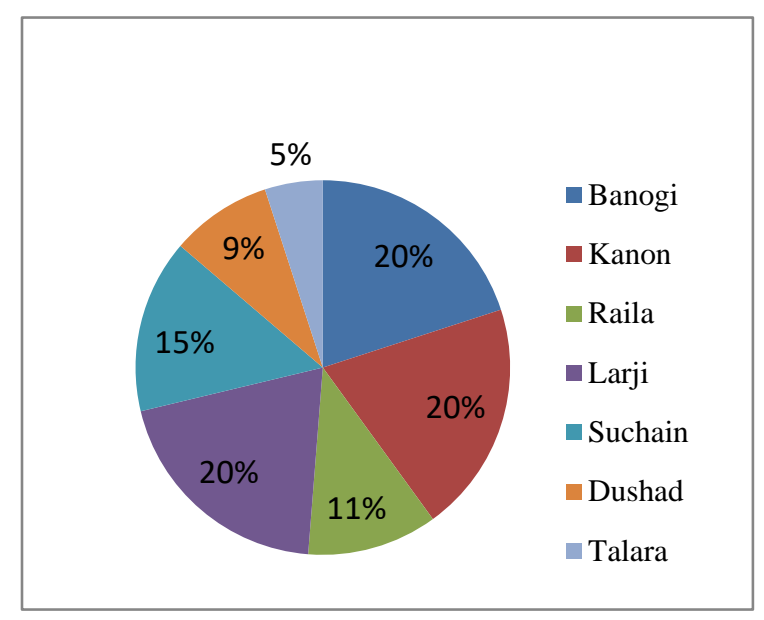

Figure 4a: Sharing 9\%) of LADE (50\%) among PAA) (07 Gram Panchayats

On evaluating the weightage of each grampanchayat among PAA as most affected area for sharing LADF, it was found that two gram-panchayats (Banogi,Kanon) got more share of LADF than their quantum of land acquisition due to impact of HEP caused by Dam, intake, DT, adit sites located in this area and other two panchayats (Suchain \& Raila) got low weightage(\%) of LADF due to comparatively low impact of HEP as depicted in fig. 5 .

The remaining $50 \%$ of LADF allocated for PAZ in three parts e.g $20 \%$ in nearby 3 nos. of Grampanchayats of PAA(Dhaugi,Rot \& Bhallan), 15\% Block (Banjar) and 15\% in District(Kullu). So the prospect of development through LADF also extends beyond the PAA to Block and district(Kullu) level due to construction of Parbati HEP-III.

After finalization of share of LADF among Grampanchayats, the proposal for requirement of development schemes of each Gram-panchayat duly passed by gram-sabha was submitted in LADC meeting for approval and releasing fund out of its share of LADF. After receipt of $1^{\text {st }}$ installment of LADF amounting to Rs 6.18 Crore from NHPC (Parbati HEP-III) by DC(Kullu)/chairman(LADC) in June 2012, the development proposal of each grampachayat was approved by the Chairman of LADC(DC,Kullu) for its execution through Block Development officer(Banjar) in a phased manner. In this way, the development process was started in PAA \& PAZ of Parbati HEP-III in Sainj Valley. 


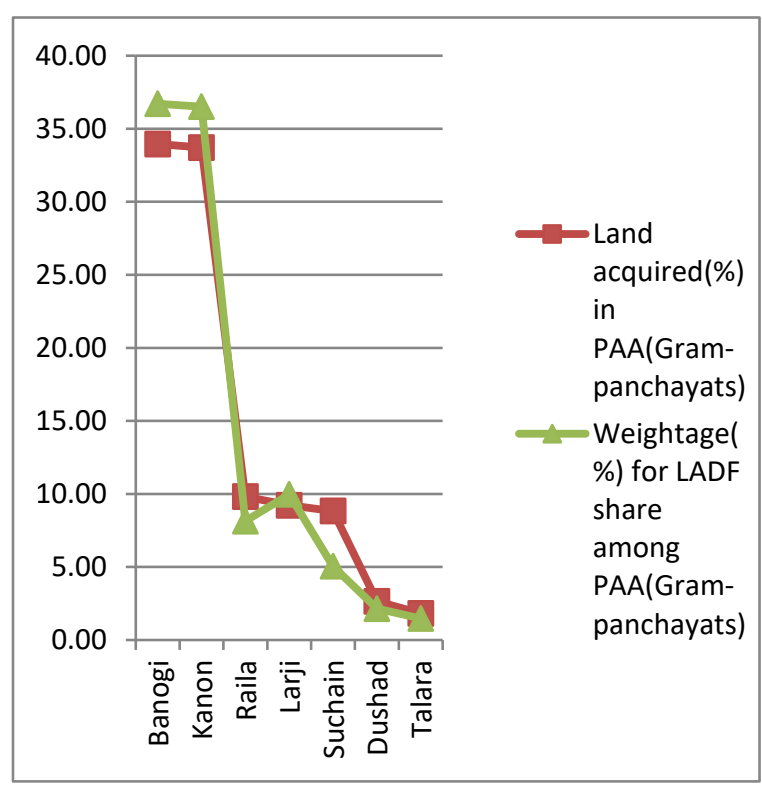

Fig-5:Weightage(\%) to each gram-panchayat(PAA) for claiming LADF Share on the.

\section{Conclusion}

Hydroelectricity is considered as renewable, cheap, reliable and environmentally benign source than the conventional source of electricity. Indian Himalayan region (IHR) is rich in hydropower potential and therefore many projects are under operation, construction and investigation stage with an aim to reduce the prevailing gap in demand and supply of electricity in India. Timely construction of HPPs in IHR is challenging due to un-availability of basic infrastructure such as access road-bridge, reliable supply of electricity, market, hospital etc by virtue of its remoteness, low population and fragile ecology. Despite abundance of natural resources in IHR, most of its people are still marginalized and still live on subsistence level. Availability and access of basic infrastructure is a part of social dimension of sustainable development. In this perspective, sustainable harnessing of hydropower potential in IHR opens the opportunity for local area development.

The project area of Parbati HE Project Stage-III is located in northwestern part of IHR. After the start of construction of Project, the roads-bridge developed in project area as per requirement of Project are now accessible to villagers of Project Affected Zone located nearby project sites. These Roads \& bridges are giving connectivity to those villages (Banau,Manham Talara, sapangini, upper sainj) in Sainj valley which were not connected to main road(State PWD Road,NH-21) prior to construction of Parbati HEP-III. Availability of better infrastructure (Road-bridge) facilitates road transport and hence business activities in the form of transport of horticulture, handicraft products, taxi services etc have also increased. Also, Road-bridge constructed for Parbati HE Project-III are also paving the way for harnessing of other small and large hydroelectric projects like Sainj HEP(100MW) and Parbati HEPII(800MW) located in the up-stream of Parbati HE project-III in a time and cost effective manner due to easy accessibility of sites in Himalayan terrain.

Besides Road-bridge, development of other civic facilities such as hospital, education facility, market avenue, socio-cultural aspects and increase in job prospects have also been improved in Sainj valley. The provision of Local Area Development Fund(LADF ) under LADA guidelines of Govt. of Himachal Pradesh and CSR guidelines of Govt. of India are new source of fund for taking-up development works in each gram-panchayat located in PAA in Sainj valley and the scope of benefits also extend up to Kullu district. Also, during the operation phase of Parbati HEP-III, there are more source of revenue for State Govt of Himachal Pradesh from Parbati HEP-III on sustained basis such as amount equivalent to $12 \%$ free power generated from project on annual basis and an additional LADF share@1\% of revenue generated from electricity as per Hydro policy of Govt. of India throughout the life span of Project. Therefore, the availability of continuous source revenue to State Govt. and execution of development works in Sainj valley are attributed to the construction of Parbati HEP-III. In the end, it is concluded that development projects have both pros and cons, therefore, while harnessing hydropotential of IHR, due care may be taken to establish a balance between socio-economic imperatives and environmental sustainability by proper planning of project and compliance to environmental norms in letter and spirit. 
Table-1: Roads \& Bridges developed in Sainj valley during construction of Parbati HEP-III.

\begin{tabular}{|c|c|c|c|c|}
\hline $\begin{array}{l}\text { Present status of road \& } \\
\text { bridge in Sainj valley }\end{array}$ & $\begin{array}{l}\text { Status prior } \\
\text { to } \\
\text { constructio } \\
\mathrm{n} \text { of Project }\end{array}$ & $\begin{array}{l}\text { Status after } \\
\text { construction } \\
\text { of Project }\end{array}$ & $\begin{array}{l}\text { Requirement of infrastructure } \\
\text { for Project }\end{array}$ & $\begin{array}{l}\text { Beneficiary villages/Gram- } \\
\text { panchayats }\end{array}$ \\
\hline $\begin{array}{l}\text { (A) } \underline{\text { ROAD }} \\
\text { (i)Larji to Sainj State } \\
\text { PWD Road(15km) }\end{array}$ & $\begin{array}{l}\text { Yes } \\
\text { (Single } \\
\text { lane) }\end{array}$ & $\begin{array}{l}\text { Yes } \\
\text { (Widen to two } \\
\text { lane \& black } \\
\text { topping) }\end{array}$ & $\begin{array}{l}\text { Free movement of traffic } \\
\text { both Project and public } \\
\text { vehicles }\end{array}$ & $\begin{array}{l}\text { Connectivity to village Larji, } \\
\text { Behali, Sapangini, Salwad, Sainj, } \\
\text { Siund. (all } 07 \text { gram-panchayats) }\end{array}$ \\
\hline $\begin{array}{l}\text { (ii) Sainj to village } \\
\text { Manham(6km) }\end{array}$ & no & yes & $\begin{array}{l}\text { Connectivity to Clay quarry } \\
\text { site at Manham }\end{array}$ & $\begin{array}{l}\text { Connectivity to villages Manham, } \\
\text { pattal to Sainj and state PWD road } \\
\text { (Sainj-Larji). } \\
\text { (Gram-panchayat-Manyashi) }\end{array}$ \\
\hline $\begin{array}{l}\text { (iii) Sainj to Suind bye- } \\
\text { pass road }\end{array}$ & no & yes & $\begin{array}{l}\text { Diverting heavy vehicles } \\
\text { from traffic congestion in } \\
\text { Sainj market Road }\end{array}$ & $\begin{array}{l}\text { Connectivity to villages Garsala, } \\
\text { upper sainj, chichuropa, Lanindhar. } \\
\text { (Gram-panchayats-Raila,Banogi) }\end{array}$ \\
\hline $\begin{array}{l}\text { (iv)Larji to Behali bye- } \\
\text { pass road(3.2km) }\end{array}$ & no & yes & $\begin{array}{l}\text { Divert traffic away from } \\
\text { Power house, \& TRT site }\end{array}$ & $\begin{array}{l}\text { Villages Behali, Sapangini, Talara } \\
\text { on right bank of river Sainj (Gram- } \\
\text { panchayats-Larji,Kanon,Talara) }\end{array}$ \\
\hline $\begin{array}{l}\text { (v) Behali to Banau } \\
\operatorname{road}(5 \mathrm{~km})\end{array}$ & no & yes & $\begin{array}{l}\text { Connectivity to surge-shaft } \\
\text { site }\end{array}$ & $\begin{array}{l}\text { Connectivity to village Banau, } \\
\text { Loul on the hill top to State PWD } \\
\text { road at behali } \\
\text { (Gram-panchayat-Larji) }\end{array}$ \\
\hline $\begin{array}{l}\text { (vi)Luri to Aut } \\
\operatorname{road}(4 \mathrm{~km})\end{array}$ & $\begin{array}{l}\text { Yes } \\
\text { (narrow } \\
\text { road) }\end{array}$ & $\begin{array}{l}\text { Yes } \\
\text { (Wide ) }\end{array}$ & $\begin{array}{l}\text { Transport of heavy } \\
\text { equipment (Turbine, rotor, } \\
\text { etc) }\end{array}$ & $\begin{array}{l}\text { Connectivity to Village Larji, } \\
\text { Banjar } \\
\text { (Gram-panchayat-Larji and Block- } \\
\text { Banjar) }\end{array}$ \\
\hline $\begin{array}{l}\text { (B) BRIDGE } \\
\text { (i)RCC bridge near Larji } \\
\text { at the confluence of } \\
\text { Trithan and Sainj } \\
\text { river }\end{array}$ & no & yes & $\begin{array}{l}\text { Free movement of traffic for } \\
\text { both Project and public } \\
\text { vehicles }\end{array}$ & $\begin{array}{l}\text { Connectivity to Sainj Valley, } \\
\text { Banjar/trithan valley, }\end{array}$ \\
\hline $\begin{array}{l}\text { (ii) RCC bridge at } \\
\text { Behali on the River } \\
\text { Sainj } \\
\end{array}$ & no & yes & $\begin{array}{l}\text { Connectivity to bye-pass } \\
\text { road from state PWD road }\end{array}$ & $\begin{array}{l}\text { Connectivity to Right bank of river } \\
\text { sainj and Larji-Behali bye pass } \\
\text { road, Sapangini }\end{array}$ \\
\hline $\begin{array}{l}\text { (iii)Baiely/suspension } \\
\text { bridge near Larji } \\
\text { on River Sainj }\end{array}$ & yes & $\begin{array}{l}\text { Yes } \\
\text { (Strengthen to } \\
\text { bear more } \\
\text { load) }\end{array}$ & $\begin{array}{l}\text { Movement of heavy vehicle } \\
\text { to reach PH \& TRT site }\end{array}$ & $\begin{array}{l}\text { Connectivity to village Larji, } \\
\text { Banjar block }\end{array}$ \\
\hline $\begin{array}{l}\text { (iv)Ropeway bridge at } \\
\text { Sainj on River } \\
\text { Sainj } \\
\end{array}$ & no & yes & For public purpose & $\begin{array}{l}\text { Connectivity to right bank of river } \\
\text { Sainj, at Sainj market }\end{array}$ \\
\hline
\end{tabular}

\section{Reference}

Altinbilek D (2002), The Role of Dams and Development. Water Resource Research 18 9-24.

Agrawal, D. K., 2001, Complexities and measures for environmental management in the Indian Himalayan region. In Environmental Impacts Assessment of Water Resources Projects (ed. Goel, R. S.),Oxford and IBH, New Delhi, 2001, pp. 403-413.

Aklilu Kahssay and Sanjay Mishra(2013) Community Development through Hydroelectric Project: A Case Study of Gilgel Gibe III Hydroelectric Power Project in Ethiopia International Journal of Community Development Vol. 1, No. 1, 2013, 19-34 DOI: 10.11634/233028791301334 ISSN 2330-2879 Print/
2330-2887 Online/ World Scholars http://www.worldscholars.org

Bose P, Pattnaik BK and Mittal M (2001). Development of socio-economic impact assessment methodology applicable to large water resource projects in India. International journal of Sustainable Development and World Ecology 8 167-180.

Bhoi Roshni \& Ali S.M., 2014 Potential of Hydro Power Plant in India and its Impact on Environment International Journal of Engineering Trends and Technology (IJETT) - Volume 10 Number 3 - Apr 2014 ISSN: 2231-5381 http://www.ijettjournal.org Page 114 Chandrasekharan M.E 1995, Case study of reservoir sedimentation in the western ghat region of kerala.in central Board of irrigation and 
power(eds),Environmental Impact Assessment Studies(case studies),pub. No.248,pp 192-197,New Delhi.)

CEA 2008, Hydro Development Plan for $12^{\text {th }}$ five year plan (2012-17) 2008). Central Electricity Authority, 2008, Hydro Development Plan for $12^{\text {th }}$ five year plan (201217)

Detail Project Report(DPR) of Parbati HE Project Stage-III, 2003, NHPC Limited(Behali), DistrictKullu(Himachal Pradesh),India

Goldemberg,J and Johansson,TB1995. 'Energy as an instrument for socio-economic development in TB and Johansson and J Goldemberg(eds), Enery for sustainable development: A policy agenda,New Yark,united nations Development programme,pp 9-17.

Goudie, A, and Viles, H, (1997). The Earth Transformed: An Introduction to Human Impacts on the Environment, Blackwell publisher, United Kingdom.GWSC, 204

Hydro Power Policy-2008, Ministry of Power, Govt. of India. http://powermin.nic.in/en/content/policy-hydropower-development, http://www.ielrc.org/content/e0820.pdf

The Company Act-2013(18 of 2013), Govt. of India, Clause135,Schedule-VII(amended), page-80

LADA-2006, 2011(amended), Govt. of Himachal Pradesh notification: Revised Guidelines for management of Local Area Development Fund (LADF) in respect of Hydro Electric Projects, No-: MPP-F (10)- 24/2011 Dt 5.10.2011

Modi, V., S. McDade, D. Lallement, J. Saghir (2006). Energy services for the millennium development goals. New York: Energy Sector Management Assistance Program, United Nations Development Program, UN Millennium Project, and World Bank. http://documents.worldbank.org/curated/en/58731146 8323723620/pdf/355050PAPER0En1MP1WB1ESMA P01PUBLIC1.pdf

Najam, Adil \& Cutler J. Cleveland (2008). Energy and sustainable development at global environmental summits. In: Encyclopedia of Earth. Eds. Cutler J. Cleveland (Washington, D.C.: Environmental information coalition, national council for science and the environment. Retrieved from http:// www.Eoearth.Org/Article/Energy_And_Sustain able_ Development_At_Global_Environmental_Summits

Paul Schuler 2007, Addressing the Social Impacts of Large Hydropower Dams The Journal of International Policy Solutions- 11 - Spring 2007, Volume 7,pg 11-17,
Price, T. and Probert, D.(1997) Harnessing hydropower: A practical guide, Applied Energy, 57, pp. 175 251.

Samant SS, Jitendra S. Butola and Aman Sharma 2007, Assessment of Diversity, Distribution, Conservation Status and preparation of Management Plan for Medicinal Plants in the Catchment Area of Parbati Hydroelectric Project Stage-III in Northwestern Himalaya. Journal of Mountain Science Vol 4 No 1(2007): Pp., 034 056.)

Singh 1991, Rong 2004: Singh S., Kothari A. and Kulan A. 1991. Evaluating major irrigation projects in India, Internatinal jouranal of Sustainalble development 1(1): $78 \sim 84 . S$

Sharma, S . and Kuniyal, J.C 2005. Hydrpower Projects in the Beas valley of H.,P: Myths and Facts. XXVII Indian Geography Congress, NAGI, Dept. of Geography \& Geoinformatics, Banglore University, Bangalore, December, 2-4,2005, Souvenir \& Abstract,Pp.57.

Subrahmanyam DS 2013, Status of Electric power generation in India with special emphasis on Hydropower expansion International Journal of Renewable Energy and Environmental Engineering Vol. 01, No. 01, October 2013

Singh, J. S. 2006, Sustainable development of the Indian Himalayan region: linking ecological and economic concerns. Curr. Sci.,2006, 90, 784-788.

Shradha Panwar, Devendra Kumar Agrawal, and Mahendra Singh Lodhi(2013) Environmental appraisal of lakhwar hydroelectric project using mathematical matrix: study from uttarakhand, India International Journal of Geology, Earth and Environmental Sciences ISSN: 2277-2081 (Online) An Online International Journal Available at http://www.cibtech.org/jgee.htm 2013 Vol. 3 (1) January-April pp.10-22/Panwar et al.

Saghir, J. (2005). Energy and poverty: myths, links, and policy issues. Energy Working Notes, no. 4. Energy and Mining Sector Board, World Bank, Washington D.C. http://siteresources.worldbank.org/INTENERGY/Reso urces/EnergyWorkingNotes_4.pdf

Sinclair,A.J 2003, Assessing the impacts of Micro-hydro development in Kullu District,H.P,India. Mountain Research and Development 23(1): 11 13.)

WCED 1987, our common future: Report of the world commission on environment and development, New Yark, Oxford university press. http://www.undocuments.net/our-common-future.pdf 